\title{
Community primary production and calcification in a NW Mediterranean ecosystem dominated by calcareous macroalgae
}

\author{
Nathaniel Bensoussan ${ }^{1, *}$, Jean-Pierre Gattuso ${ }^{2}$ \\ ${ }^{1}$ Laboratoire Diversité, évolution et écologie fonctionnelle marine, CNRS-Université de la Méditerranée, \\ Centre d'Océanologie de Marseille, Station Marine d'Endoume, rue Batterie des Lions, 13007 Marseille, France \\ ${ }^{2}$ Laboratoire d'Océanographie de Villefranche, CNRS-Université de Paris 6, BP 28, 06234 Villefranche-sur-mer Cedex, \\ France
}

\begin{abstract}
The community metabolism of a shallow infralittoral ecosystem dominated by the calcareous macroalgae Corallina elongata was investigated in Marseilles (NW Mediterranean), by monitoring hourly changes of seawater $\mathrm{pH}$ and total alkalinity over $6 \mathrm{~d}$ in February 2000. Fair weather conditions prevailed over the study period as indicated by oceanographic (temperature, salinity, and current velocity and direction) and meteorological variables, which validated the standing water hypothesis. This temperate ecosystem exhibited high community gross primary production (GPP = $519 \pm 106 \mathrm{mmol} \mathrm{C} \mathrm{m} \mathrm{d}^{-2} \mathrm{~d}^{-1}, \mathrm{n}=6$ ) and also supported high rates of community respiration $(R)$. As a result, the system was slightly autotrophic (net community production, NCP $=20 \mathrm{mmol} \mathrm{C} \mathrm{m}^{-2} \mathrm{~d}^{-1}$ ), with a GPP/R ratio of 1.06 . NCP exhibited circadian variations with 2 - to 3 -fold changes in community respiration, both in the light and in the dark. Rates of net community calcification also exhibited circadian variations, with positive rates (up to $24 \mathrm{mmol} \mathrm{CaCO}_{3} \mathrm{~m}^{-2} \mathrm{~h}^{-1}$ ) for irradiance values $>300 \mathrm{~W}$ $\mathrm{m}^{-2}$ (about $1380 \mu \mathrm{mol}$ photon $\mathrm{m}^{-2} \mathrm{~s}^{-1}$ ). Below this irradiance threshold, net community dissolution prevailed. Daily net calcification $(G)$ was on average $8 \mathrm{mmol} \mathrm{CaCO}_{3} \mathrm{~m}^{-2} \mathrm{~d}^{-1} \cdot \mathrm{CO}_{2}$ fluxes generated by primary production, respiration, and calcification suggest that the study site was a potential atmospheric $\mathrm{CO}_{2}$ sink of $15 \mathrm{mmol} \mathrm{CO} \mathrm{CO}^{-2} \mathrm{~d}^{-1}$ at the time of measurement.
\end{abstract}

KEY WORDS: Ecosystem metabolism · Primary production $\cdot$ Respiration $\cdot$ Calcification $\cdot$ Calcareous macroalgae $\cdot$ Corallina elongata $\cdot \mathrm{pH} \cdot$ Total alkalinity $\cdot \mathrm{TA}$

Resale or republication not permitted without written consent of the publisher

\section{INTRODUCTION}

The coastal zone is characterized by large spatial changes in ecosystem distribution and temporal changes in biological processes, which generate strong gradients of biogeochemical fluxes in space and time. The role of the coastal zone in the carbon cycling, as well as its trophic status, is still a matter of debate (Gattuso et al. 1998, Mackenzie et al. 2004, Duarte et al. 2005), partly due to large differences between proximal and distal parts of the coastal ocean and the lack of a typology, which would enable extension of the data from a local scale to regional and global scales (Gazeau et al. 2004). Marine macrophytes are major contributors to benthic photoautotrophy in many prox- imal coastal ecosystems, so-called macrophyte-dominated ecosystems, which are among the most productive systems and also account for much of the respiration in coastal zones (Gattuso et al. 1998, Middelburg et al. 2005).

The organic carbon metabolism (photosynthesis and respiration) of seagrass communities has been examined since the introduction of metabolic studies in aquatic ecology, largely through the use of benthic chambers. In contrast to seagrasses - although net primary production data are available for several species of macroalgae (e.g. Littler 1980) - the organic carbon metabolism of macroalgal-dominated systems has only been examined in a relatively limited number of studies. In particular, very few data are available for 
temperate climate regions, as pointed out in recent reviews addressing the European (Gazeau et al. 2004) and global (Gattuso et al. 1998, Middelburg et al. 2005) coastal zones.

High levels of gross primary production (GPP) in macroalgal-dominated marine communities were first reported in reef systems by Smith \& Marsh (1973). Despite high levels of autotrophic activity, the net ecosystem metabolism (i.e. net community production, NCP), which is the difference between GPP and ecosystem respiration $(R)$, appears nearly balanced in most studies.

Shallow-water ecosystems have also proved to be significant contributors to the global inorganic carbon cycle (Mackenzie et al. 2004, Muller-Karger et al. 2005). Approximately $25 \%$ of the global precipitation of calcium carbonate and $50 \%$ of $\mathrm{CaCO}_{3}$ accumulation occur in coastal regions (Milliman 1993, Wollast 1998). It must, however, be noted that estimates of $\mathrm{CaCO}_{3}$ production may be biased because a relatively large amount of data is available for coral reefs (reviewed by Gattuso et al. 1998), but comparatively little information is available on temperate systems.

Although calcification and photosynthesis both decrease the dissolved inorganic carbon (DIC) concentration, they displace the carbonate equilibrium in opposing directions, increasing and decreasing the partial pressure of $\mathrm{CO}_{2}\left(\mathrm{pCO}_{2}\right)$, respectively. A simple model was derived to predict the effect of the organic and inorganic metabolic activities on air-sea $\mathrm{CO}_{2}$ fluxes (Gattuso et al. 1995). In addition, the precipitation of $1 \mathrm{~mol}$ of $\mathrm{CaCO}_{3}$ decreases total alkalinity (TA)

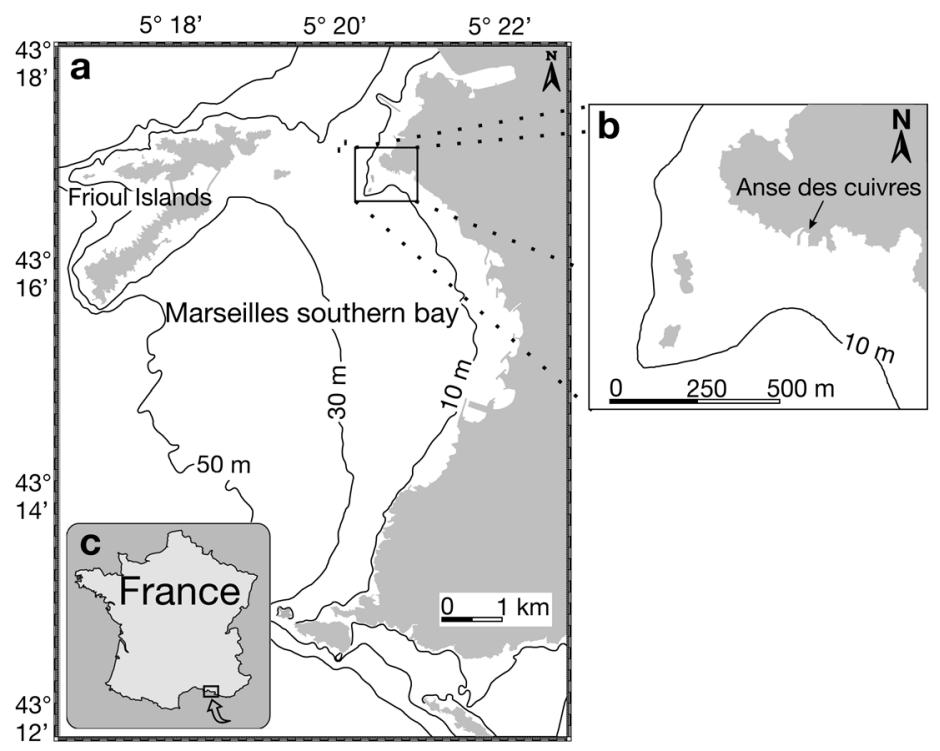

Fig. 1. Location map of the study site: (a) Marseilles southern bay, (b) Endoume coastal area, (c) Marseilles southern bay in relation to France by 2 mol. Thus, both net organic carbon metabolism and carbonate dynamics, hereafter collectively referred to as community metabolism, are important to study in order to address the role of coastal ecosystems in the $\mathrm{C}$ cycle. Despite a 13-fold increase in the publication rate of coastal biogeochemistry studies since 1971, important gaps in knowledge still exist (Gattuso et al. 2005). Indeed, carbonate dynamics in coastal ecosystems represent a very marginal proportion $(<1 \%)$ of coastal biogeochemistry studies. Furthermore, ecosystems exhibiting high rates of primary production such as algal beds and seagrass meadows have been subject to comparatively little investigation (8\%).

In temperate regions, such as in the Mediterranean Sea, calcareous macroalgae can thrive and dominate in a large range of habitats, from the mediolittoral to the deepest part of the photic layer (Canals \& Ballesteros 1997). To the best of our knowledge, simultaneous measurements of organic and inorganic carbon metabolism at the ecosystem level have never been conducted in such an environment. The present study investigated the winter time community metabolism of a Mediterranean marine shallow ecosystem dominated by the Corallina elongata community (Ballesteros 1988), employing the pH-TA technique (Smith \& Key 1975).

\section{MATERIALS AND METHODS}

Study site and community composition. The study site (Anse des Cuivres, NW Mediterranean Sea; Fig. 1) is a shallow cove (surface area: ca. $900 \mathrm{~m}^{2}$; average depth: $3 \mathrm{~m}$ ) dominated by hard substratum (ca. $<30 \%$ soft bottoms). It is relatively sheltered from the dominant NW winds and opens to the southern bay of Marseilles. The rocky substratum, including vertical walls, exhibits high surface cover by the Corallina elongata community, which is typical of the rocky NW Mediterranean infralittoral (Ballesteros 1988). C. elongata biomass ranged from 820 to $2544 \mathrm{~g}$ dry weight (DW) $\mathrm{m}^{-2}$ (El Haïkali et al. 2004). Among the other conspicuous calcareous macroalgae are the articulated species Jania corniculata and Amphiroa rubra and the encrusting species Mesophyllum alternans and Lithophyllum lichenoides.

Field measurements. Meteorological and oceanographic measurements were conducted during the period 23-29 February 2000. A Davies Weather Monitor 2 station located on the roof of the laboratory ( $20 \mathrm{~m}$ from the study site) recorded wind speed and direction every $30 \mathrm{~min}$. Surface irradiance $\left(\mathrm{W} \mathrm{m}^{-2}\right)$ was measured using a LI-COR LI-190SA pyranometer sensor (400 to $800 \mathrm{~nm}$ ), with a LI-185B interface. It was also expressed in 


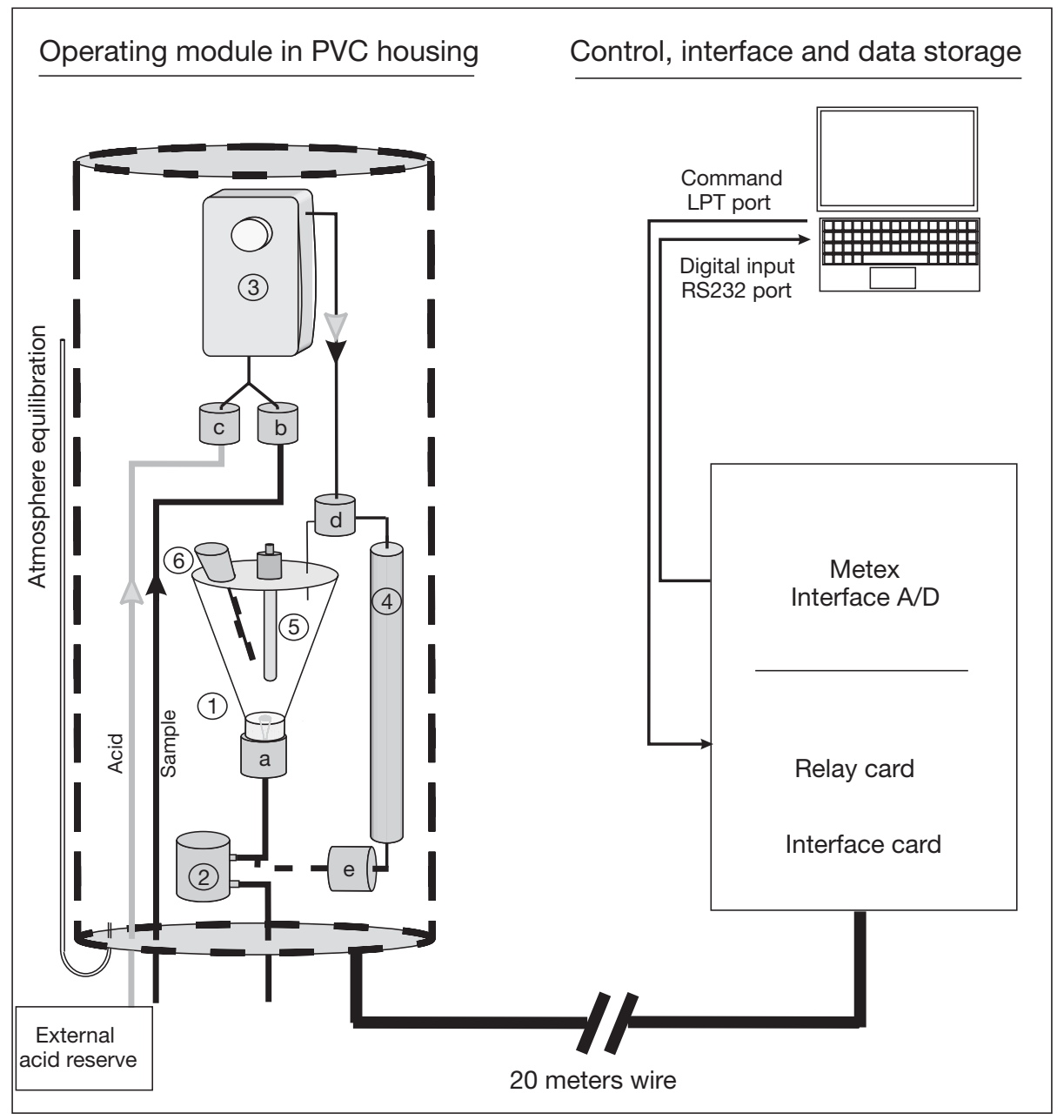

Fig. 2. Schematic representation of the automatic module for alkalinity measurement. See the 'Field measurements' section in 'Materials and methods' for more details

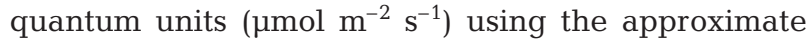
conversion factor according to Morel \& Smith (1974). Seawater temperature $(T)$ and salinity $(S)$ were measured by a WTW LF197S cell immersed to $1.5 \mathrm{~m}$ depth. Irradiance, $T$, and $S$ data were sampled every $50 \mathrm{~s}$ and averaged over $30 \mathrm{~min}$. Current intensity and direction were measured every $5 \mathrm{~min}$ and averaged over $30 \mathrm{~min}$ until 26 February at 10:00 h, with an upward-directed Sontek ADP (acoustic Doppler profiler) dedicated to shallow-water deployment $(20 \mathrm{~cm}$ high cells); the ADP was moored at $4.2 \mathrm{~m}$ depth at the opening of the Anse des Cuivres (Fig. 1).

The $\mathrm{pH}$ and TA were measured every hour from 01:00 to 23:00 h by an automatic module for alkalinity measurement (AMAM; Fig. 2) operating in situ in surface water. This unit sampled seawater $(100 \mathrm{ml})$, and $\mathrm{pH}$ was first measured. Then, the sample was acidified, and TA was estimated from final-end-point potentiometric titration. The measurement module is con- nected to the command box (power supply, electronic and relay cards) by a $20 \mathrm{~m}$ wire. At the start of each measurement, the polycarbonate conical $250 \mathrm{ml}$ measuring cell (1 in Fig. 2), fitted on the bottom with a pump (2), behind a solenoid valve (a), is first drained of the previous acidified sample then rinsed twice with seawater. A precision electronic piston pump (contiburette $\mu 10 \mathrm{MO}$ laboCAT, $0.1 \%$ accuracy) (3) is used for seawater (100 ml, filtered on $125 \mu \mathrm{m})$ and acid $(30 \mathrm{ml}$; ionic strength: 0.7) delivery, using 2 upstream independent tubes, each of them fitted with its own solenoid valve (b for seawater, $\mathrm{c}$ for acid). Injection is done at the top of the cell by a Teflon tube $(1 \mathrm{~mm}$ inner diameter). Between the seawater and acid injection phases, all the piston pump tubes are purged and rinsed into an internal reservoir (4) used to collect residual volumes from injection circuit rinsing. An electric rotary stirrer (5) is used to homogenize the solution before $\mathrm{pH}$ measurement by a $\mathrm{pH}$ probe 
(Hanna Instrument with built-in amplification circuits) (6) located at the top of the measuring cell. All liquid junctions are constructed in silicon tubing, and the 5 solenoid valves (a to e) enable or disable fluid circulation for sample or acid injection, cell rinsing and draining, and purging into the internal reservoir or its draining. Electrode voltage outputs are digitized by an 8 bit A/D (analog to digital) converter (Metex M 4650-CR, $\pm 0.05 \mathrm{mV}$ accuracy, $0.02 \mathrm{mV}$ resolution) and transmitted to a computer. The $\mathrm{pH}$ was recorded over $30 \mathrm{~s}$ at $1 \mathrm{~Hz}$. The resulting means and SDs were saved.

Before initiation of the experiment, the linearity of the electrode was tested and calibration was performed using N-bromo-succinimide (N.B.S.) buffers (Merck; 4.01, 7.01, and 10.01 at $25^{\circ} \mathrm{C}$ ). The reproducibility of the AMAM was determined on filtered surface seawater $(\mathrm{n}=17)$. For $\mathrm{pH}$ and $\mathrm{TA}$, uncertainties were $\pm 0.002 \mathrm{pH}$ units and $\pm 3 \mu \mathrm{mol} \mathrm{kg} \mathrm{kg}^{-1}(1 \mathrm{SD})$, respectively. TA values estimated with the AMAM instru-


carried out in the laboratory using final-end-point titration. TA was normalized to a salinity of $38\left(\mathrm{TA}_{38}=\right.$ TA $\times 38 / S$ ) to remove the changes due to salinity variations.

Community productivity and calcification. Calcification and partitioning of organic and inorganic carbon metabolism were estimated using the alkalinity anomaly ( $\mathrm{pH}-\mathrm{TA}_{i}$ Smith \& Key 1975). DIC was calculated from $\mathrm{pH}$ and TA with the CO2SYS program (Lewis \& Wallace 1998) using the Peng option for dissociation constants on the N.B.S. scale. Since instantaneous air-sea $\mathrm{CO}_{2}$ fluxes were negligible $(<0.2 \mathrm{mmol}$ $\mathrm{m}^{-2} \mathrm{~h}^{-1}$ ) compared to $\Delta \mathrm{DIC}$, net primary production and calcification were computed as follows:

$$
\begin{aligned}
\text { ncp } & =-\Delta \mathrm{DIC} \rho z-g \\
g & =-1 / 2 \Delta \text { TA } \rho z
\end{aligned}
$$

where ncp is net community production $\left(\mathrm{mmol} \mathrm{m}^{-2} \mathrm{~h}^{-1}\right)$, $g$ is community calcification $\left(\mathrm{mmol} \mathrm{m}^{-2} \mathrm{~h}^{-1}\right), \rho$ is seawater density $\left(\mathrm{kg} \mathrm{m}^{-3}\right), z$ is water depth $(\mathrm{m})$ and $\Delta \mathrm{DIC}$ and $\Delta$ TA are hourly changes in DIC and total alkalinity $\left(\mathrm{mmol} \mathrm{kg} \mathrm{k}^{-1} \mathrm{~h}^{-1}\right)$. By convention, lower case letters refer to hourly fluxes and capital letters refer to fluxes integrated over the day, night, or $24 \mathrm{~h}$ (Eqs. 1 to 4).

Computation of daily metabolic budgets. Net daily ecosystem primary production was calculated as described by Falter et al. (2001). Briefly, ncp was integrated from sunrise to sunset to yield the net ecosystem production that occurs during the daylight hours $\left(\mathrm{NCP}_{\text {light }}\right)$ and from sunset to sunrise to yield the nighttime respiration in the dark $\left(R_{\text {dark }}\right)$.

GPP and $R$ were calculated as follows:

$$
\begin{aligned}
\mathrm{GPP} & =\mathrm{NCP}_{\text {light }}+R_{\text {light }} \\
R & =R_{\text {light }}+R_{\text {dark }}
\end{aligned}
$$

where $R_{\text {light }}$ is the community respiration rate in the light, assuming that hourly rates of light and dark respiration are similar. This neglects the possibility that $R_{\text {light }}$ may be higher than $R_{\text {dark, }}$ as shown in a largescale coral reef mesocosm (Langdon et al. 2003).

Daily net calcification rate $(G)$ was calculated by integrating the hourly rates of calcification over $24 \mathrm{~h}$.

\section{RESULTS}

\section{Environmental and hydrodynamic conditions}

Total irradiance and its distribution during the course of the days were similar throughout the experiment with, for maximum irradiance levels $\left(540 \mathrm{~W} \mathrm{~m}^{-2}\right.$, about $2485 \mu \mathrm{mol}$ photons $\mathrm{m}^{-2} \mathrm{~s}^{-1}$ ), an SD of $<2 \%$ of the mean $(n=6)$. Low to moderate $\left(1.6 \pm 1.4 \mathrm{~m} \mathrm{~s}^{-1}, \mathrm{n}=322\right)$ NW winds were dominant, and the wind speed was higher during the day than at night (2.1 vs. $1.2 \mathrm{~m} \mathrm{~s}^{-1}, t$ test, $\mathrm{p}<0.0001)$. A transient peak occurred on 25 February $\left(6.6 \mathrm{~m} \mathrm{~s}^{-1}\right)$. Current velocity was low $(1.8 \pm 0.6 \mathrm{~cm}$ $\mathrm{s}^{-1}, \mathrm{n}=3240$ ), and did not exhibit any circadian or vertical patterns. The third quartile of current intensity distribution was $2.2 \mathrm{~cm} \mathrm{~s}^{-1}$, and maximum values were $<4 \mathrm{~cm} \mathrm{~s}^{-1}$, except in the surface layer during the wind event of 25 February. Temperature $\left(12.6 \pm 0.6^{\circ} \mathrm{C}\right)$ and salinity $(37.76 \pm 0.04)$ showed typical winter values for the area. As a result of the calm and sunny conditions, seawater temperature exhibited weak diurnal variations $\left(0.7^{\circ} \mathrm{C}\right)$ and a significant linear trend against time $\left(+0.25^{\circ} \mathrm{C} \mathrm{d}^{-1}, \mathrm{r}=0.89, \mathrm{n}=322\right)$.

\section{$\mathrm{CO}_{2}$ related parameter dynamics}

Large $\mathrm{pH}$ and TA changes of, respectively, 0.243 and $126 \mu \mathrm{mol} \mathrm{kg} \mathrm{kg}^{-1}$ were recorded over the study period. The $\mathrm{pH}$ exhibited regular and synchronous circadian changes from day to day, with minima around 08:00 h and maxima around 17:00 h (Fig. 3A). TA 38 variations were noisier, but also displayed significant diurnal changes, with a slight increase trend from midnight to sunrise, a marked decrease $\left(-41 \pm 23 \mu \mathrm{mol} \mathrm{kg}{ }^{-1}, \mathrm{n}=6\right)$ between late morning $(11: 00 \mathrm{~h})$ and mid-afternoon (15:00 h), and relatively stable values from $15 \mathrm{~h}$ to midnight (Fig. 3B). A significant trend against time was observed for $\mathrm{TA}_{38}\left(-7 \mu \mathrm{mol} \mathrm{kg}{ }^{-1} \mathrm{~d}^{-1}, \mathrm{r}=0.46, \mathrm{n}=152\right)$.

\section{Primary production and calcification}

Hourly ncp showed diurnal changes (Fig. 4) and reached the highest values $\left(60 \pm 9 \mathrm{mmol} \mathrm{C} \mathrm{m}^{-2} \mathrm{~h}^{-1}\right)$ at solar noon (13:00 $\mathrm{h}$ local time). The compensation irra- 
diance was lower in the morning than in the afternoon $\left(40\right.$ vs. $280 \mathrm{~W} \mathrm{~m}^{-2}$, i.e. 198 vs. $1293 \mu \mathrm{mol}$ photons $\mathrm{m}^{-2}$ $\mathrm{s}^{-1}$ ). The rate of respiration in the dark exhibited a consistent negative trend during the course of the night. It was highest $1 \mathrm{~h}$ after sunset $\left(-47 \mathrm{mmol} \mathrm{m}^{-2} \mathrm{~h}^{-1}\right)$ and decreased to significantly lower $\left(-13 \mathrm{mmol} \mathrm{m}^{-2} \mathrm{~h}^{-1}\right.$; $z$-test, $\mathrm{p}<0.0001$ ) and relatively constant levels during the second part of the night (01:00 to 07:00 h).

Calcification also showed a strong diurnal pattern (Fig. 4). Net calcification was observed with rates up to $24 \pm 10 \mathrm{mmol} \mathrm{CaCO}_{3} \mathrm{~m}^{-2} \mathrm{~h}^{-1}$ for irradiance values
$>300 \mathrm{~W} \mathrm{~m}^{-2}$ (about $1380 \mu \mathrm{mol}$ photons $\mathrm{m}^{-2} \mathrm{~s}^{-1}$ ). Net $\mathrm{CaCO}_{3}$ dissolution prevailed below that threshold (average of $-3 \mathrm{mmol} \mathrm{CaCO}_{3} \mathrm{~m}^{-2} \mathrm{~h}^{-1}$ ).

The mean community GPP and $R$ were $519 \pm 106$ and $500 \pm 136 \mathrm{mmol} \mathrm{C} \mathrm{m}^{-2} \mathrm{~d}^{-1}( \pm \mathrm{SD})$, respectively. There was therefore a slightly positive NCP $(19 \mathrm{mmol}$ $\mathrm{C} \mathrm{m}^{-2} \mathrm{~d}^{-1}$ ). Despite the strong variability of GPP (342 to $657 \mathrm{mmol} \mathrm{C} \mathrm{m}^{-2} \mathrm{~d}^{-1}$ ) and $R$ ( 277 to $671 \mathrm{mmol} \mathrm{C} \mathrm{m}^{-2} \mathrm{~d}^{-1}$ ), the GPP: $R$ ratio always remained close to $1(1.1 \pm 0.1$, $\mathrm{n}=6)$. $G$ varied greatly from one day to the next and ranged from -33 (net dissolution) to +39 (net calcifica-

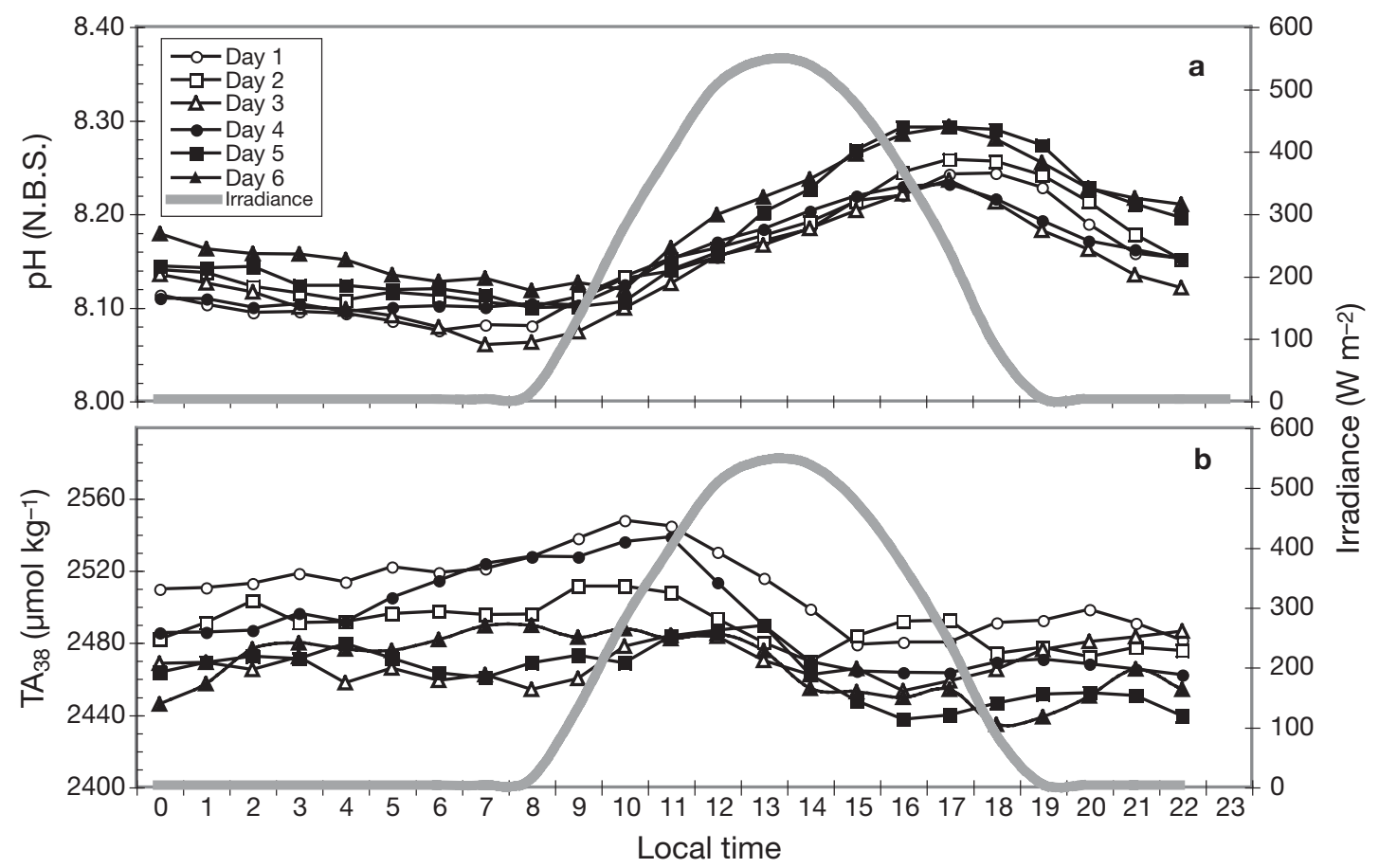

Fig. 3. (a) $\mathrm{pH}$ (using N-bromo-succinimide [N.B.S.] buffers $4.01,7.01$, and 10.01 at $25^{\circ} \mathrm{C}$ ) and (b) $\mathrm{TA}_{38}$ (total alkalinity normalized to a salinity of 38 ) time series at the study site. Hourly mean irradiance levels also plotted

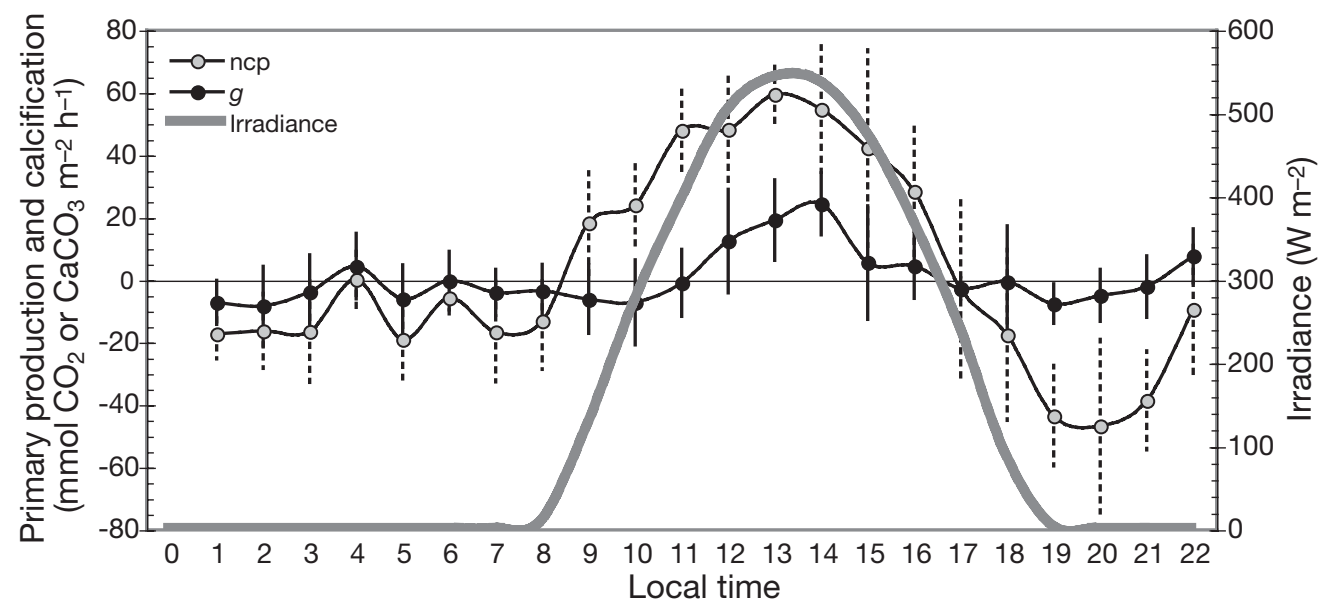

Fig. 4. Mean hourly rates of primary production and calcification over $6 \mathrm{~d}$ by the pH-TA technique. Mean hourly irradiance levels also plotted. Error bars: \pm SD 
tion) $\mathrm{mmol} \mathrm{CaCO}_{3} \mathrm{~m}^{-2} \mathrm{~d}^{-1}$. Its mean value for the study period was $8 \pm 32 \mathrm{mmol} \mathrm{CaCO}_{3} \mathrm{~m}^{-2} \mathrm{~d}^{-1}$. The mean G:GPP ratio was 0.015 .

\section{DISCUSSION}

\section{Ecosystem primary production and calcification}

The current velocity was mostly $<2 \mathrm{~cm} \mathrm{~s}^{-1}$ during the first $3 \mathrm{~d}$ of the experiment; hence, the water mass was likely relatively still. No current data are available for the remaining $3 \mathrm{~d}$, but it is reasonable to assume that requirements for the standing water approach were met during the whole study, as wind speed was not significantly greater during the subsequent $3 \mathrm{~d}(t$-test, $\mathrm{p}=0.36$, $\mathrm{n}=144$ ). The assumption of low water exchange between the cove and the open water is strongly reinforced by a simple budget. The expected decrease in TA in the cove is about $5.2 \mu \mathrm{mol} \mathrm{kg}{ }^{-1} \mathrm{~d}^{-1}\left(8000 \mu \mathrm{mol} \mathrm{CaCO} \mathrm{Cm}^{-2}\right.$ $\mathrm{d}^{-1} / \rho z$, with $\rho=1028.6 \mathrm{~kg} \mathrm{~m}^{-3}$ and $z=3 \mathrm{~m}$ ). This value reflects very well the significant negative trend of $7 \mu \mathrm{mol}$ $\mathrm{kg}^{-1} \mathrm{~d}^{-1}$ observed during the experiment.

The hourly time series of net primary production and calcification during 6 successive days provides insight on short-term changes in the diurnal cycle and reveals original dynamics.

The gpp: $r$ ratio decreases during the afternoon, as shown by the high afternoon compensation irradiance (280 $\mathrm{W} \mathrm{m}^{-2}$, about $1293 \mu \mathrm{mol}$ photons $\mathrm{m}^{-2} \mathrm{~s}^{-1}$; data not shown) and the previous ncp decrease. As the system studied harbors photophilic benthic macroalgae, an increase in $R$, rather than a decline in photosynthesis resulting from photoinhibition, is likely responsible for the afternoon depression. From a simple graphic approach based on the $\mathrm{CO}_{2}$ data (Fig. 4), a 2- to 3-fold increase can be inferred between morning and afternoon $R$ rates.

The rates of $R_{\text {dark }}$ were also quite variable (Fig. 4), decreasing 3 -fold to relatively constant values during the first part of the night. Similar night-time $R$ dynamics were also observed in early water-flow metabolic studies, but neglected in the computation of daily metabolic parameters by the diurnal curve method, since the $R$ baseline was '...drawn through the night time $R$ rates after they have achieved a constant value' (Marsh \& Smith 1978). Langdon (1993) also reported a decrease in $R$ rate through the night in large phytoplankton incubation chambers. More recently, during a field enclosure study of macroalgal-dominated coral reef community metabolism, Gattuso et al. (1997) observed considerable scatter (ca. 3-fold) of night-time $R$ rates. Such variability was not observed in a large coral reef mesocosm (Falter et al. 2001, Langdon et al. 2003).
It has been established that $R_{\text {light }}$ often exceeds $R_{\text {dark }}$ in micro- and macroalgae as well as in zooxanthellae in hospite. Employing a new ${ }^{14} \mathrm{C}$ isotope dilution method in the Biosphere 2 coral reef mesocosm largely dominated by macroalgae, Langdon et al. (2003) showed that $R_{\text {light }}$ was twice as high as $R_{\text {dark }}$. Differences between $R_{\text {dark }}$ and $R_{\text {light }}$ rates have direct consequences for the conventional estimate of GPP and $R$, which might be underestimated by as much as $40 \%$ (Langdon et al. 2003), but not for the estimate of NCP.

However, rather than strictly opposing values for daylight and darkness periods, our observations suggest large (up to 3-fold) variations in respiratory activity under both daylight and dark conditions, with significantly higher $R$ rates during the afternoon and the first part of the night. This dynamic relationship supports the hypotheses that a photosynthetically produced pool of dissolved organic matter is oxidized and short-term coupling occurs between photosynthesis and $R$ (Falter et al. 2001).

Community net calcification $(g)$ also exhibited marked diurnal variations, with highest $\mathrm{CaCO}_{3}$ deposition rates during the period of maximum irradiance. There were numerous $\mathrm{CaCO}_{3}$ depositing organisms at the study site, conspicuously macroalgae, among which Corallina elongata exhibited both the highest biomass (820 to $2544 \mathrm{~g} \mathrm{DW} \mathrm{m}^{-2}$ ) and the highest calcification rate, with a light to dark calcification ratio of 3.6 (El Haïkali et al. 2004). Calcification and photosynthesis are directly linked in organisms showing light-enhanced calcification. However, unlike ncp, $g$ was positive (net $\mathrm{CaCO}_{3}$ deposition) for irradiances $>300 \mathrm{~W} \mathrm{~m}^{-2}\left(1380 \mu \mathrm{mol}\right.$ photons $\left.\mathrm{m}^{-2} \mathrm{~s}^{-1}\right)$. Differences in calcification and primary production dynamics or in the light ressponse curve are not surprising at the system level (see for example Barnes \& Devereux 1984, Gattuso et al. 1996, 1997), but our observations are in contrast to previous results for coral reefs, where net $\mathrm{CaCO}_{3}$ deposition is sometimes measured both during the day and at night (Gattuso et al. 1996) and, in a macroalgal-dominated coral reef community in Moorea (French Polynesia), where net $\mathrm{CaCO}_{3}$ deposition was measured at irradiances $>500 \mu \mathrm{mol}$ photons $\mathrm{m}^{-2} \mathrm{~s}^{-1}$ (Gattuso et al. 1997). The alkalinity anomaly technique provides access to net calcification only (i.e. the $\mathrm{CaCO}_{3}$ precipitation/dissolution balance). Nevertheless, night- time negative $g$ values (when macroalgae still deposit $\mathrm{CaCO}_{3}$ ) - and apparent high irradiance requirements for positive $g$ values-suggest high $\mathrm{CaCO}_{3}$ dissolution rates within the system, as also indicated by the comparison of our data with direct estimate of $C$. elongata calcification rates (see below).

From a 3 yr study using the $\mathrm{O}_{2}$ method in the Biosphere 2 mesocosm, Falter et al. (2001) made the sur- 
prising observation that the variance of NCP at a time scale of $<1$ wk was significantly larger than the variance at all other time scales. Our observations suggest that the short-term variability of primary production and calcification can be even greater in natural open systems and support their conclusions on the need of longer time integration than usually conducted in order to estimate community metabolism.

However, due to the time variations in biotic and abiotic factors such as community composition, nutrients, temperature, daylength, and irradiance, more data covering seasonal variations are needed before attempting an annual estimate of community metabolism.

\section{Biologically induced $\mathrm{CO}_{2}$ fluxes}

In a calcifying system, several processes occur during the day, either increasing (calcification and respiration) or decreasing (dissolution of $\mathrm{CaCO}_{3}$ and photosynthesis) the seawater $\mathrm{pCO}_{2}$ level. When GPP and $R$ are nearly balanced, increased seawater $\mathrm{pCO}_{2}$ induced by calcification can dominate biologically induced $\mathrm{CO}_{2}$ fluxes, which explains why most reef flats behave as sources of $\mathrm{CO}_{2}$ (Gattuso et al. 1999). Applying the model derived by Gattuso et al. (1995) to the average metabolic rates estimated in this work $\left(\mathrm{NCP}=20.8\right.$ and $\left.G=8.4 \mathrm{mmol} \mathrm{m}^{-2} \mathrm{~d}^{-1}\right)$, the Anse des Cuivres was a potential net sink of atmospheric $\mathrm{CO}_{2}$ of $15 \mathrm{mmol} \mathrm{CO}_{2} \mathrm{~m}^{-2} \mathrm{~d}^{-1}$ at the time of the experiment. This is the first estimate of potential fluxes for a shallow temperate system dominated by calcareous macroalgae. Further metabolic investigations at the relevant time scales are required to determine the annual metabolic balance and its net influence on the $\mathrm{pCO}_{2}$ of surrounding waters, which is all the more important when the water volume is low and the water residence time is high. However, despite very large gross metabolic rates, the influence of macrophyte-based ecosystems on air-sea $\mathrm{CO}_{2}$ fluxes in temperate coastal zones may not be prominent. Indeed, shallow (7 m) Posidonia oceanica-vegetated sediments in Palma Bay (western Mediterranean Sea) were found to be a potential net $\mathrm{CO}_{2}$ sink of only $1 \mathrm{mmol} \mathrm{CO} \mathrm{CO}^{-2} \mathrm{~d}^{-1}$, as a mean on the annual scale due to slight autotrophy and net $\mathrm{CaCO}_{3}$ deposition (Barrón et al. 2006). Furthermore, the solubility coefficient of $\mathrm{CO}_{2}$ is strongly dependant on temperature, which is the driving factor in the seasonal variability of air-sea $\mathrm{CO}_{2}$ fluxes in the western Mediterranean Sea. As a result, Gazeau et al. (2005) suggest that $P$. oceanica meadows could only decrease the summer-time $\mathrm{CO}_{2}$ emission from the Mediterranean continental shelf by a modest $2.5 \%$.

\section{Comparison with other macroalgal-dominated ecosystems and significance for the coastal budget}

Considering an average microphytobenthic GPP of $16 \mathrm{mmol} \mathrm{C} \mathrm{m} \mathrm{m}^{-2} \mathrm{~d}^{-1}$ for the 0 to $5 \mathrm{~m}$ depth range in the Mediterranean Sea (Gazeau et al. 2004) and a planktonic primary production of about $8 \mathrm{mmol} \mathrm{C} \mathrm{m}{ }^{-2} \mathrm{~d}^{-1}$ in winter (Lefèvre et al. 1997), macroalgae and epiphytic microalgae must be the main contributors to GPP at the study site. Despite a community structure based on calcareous macrophytes (which are low productivity species according to the functional form model of Littler 1980), the GPP of Anse des Cuivres in winter is slightly greater than the average value for macrophytedominated systems (519 vs. 477 mmol C m${ }^{-2} \mathrm{~d}^{-1}$; Gattuso et al. 1998) due to high biomass. Reports on GPP and $R$ of macrophyte-dominated benthic systems span over $>1$ order of magnitude (Table 1 ). This variability is due to the absolute and relative surface area covered by the major communities and the type of substrate, which seems to overwhelm the effect of environmental variables and the dominant species.

$R$ is close to GPP and stands close to the average rate reported by Middelburg et al. (2005) for macroalgaldominated benthic systems (500 vs. $483 \mathrm{mmol} \mathrm{C} \mathrm{m}^{-2} \mathrm{~d}^{-1}$ ).

In agreement with most reports on the metabolism of macrophyte-dominated benthic systems, the Anse des Cuivres was autotrophic at the time of measurement. The GPP: $R$ ratio was nearly balanced, and NCP $\left(19 \mathrm{mmol} \mathrm{m}^{-2} \mathrm{~d}^{-1}\right)$ was ca. $5 \%$ of GPP.

Reports on calcification rates primarily arise from coral reef ecosystems, where absolute and relative surface coverage as well as community structure explain strong differences in calcification rates at small spatial scales (Kinsey 1985). High levels of $\mathrm{CaCO}_{3}$ deposition (66 to $110 \mathrm{mmol} \mathrm{m}^{-2} \mathrm{~d}^{-1}$ ) were measured in algal pavement zones (Kinsey 1985), while slight net $\mathrm{CaCO}_{3}$ dissolution $\left(-0.8 \mathrm{mmol} \mathrm{m}^{-2} \mathrm{~d}^{-1}\right)$ prevailed at fringing reefs dominated by macroalgae (Gattuso et al. 1997). Our estimate indicates moderate calcification rates in the system studied ( $8 \mathrm{mmol} \mathrm{CaCO}_{3} \mathrm{~m}^{-2} \mathrm{~d}^{-1}$ ), with a G:GPP ratio (0.02) 1 order of magnitude lower than at coral reefs (0.2 to 0.3 ; Langdon et al. 2000). This estimate is in good agreement with the total carbonate production of photophilic algae on the Mallorca-Menorca shelf (NW Mediterranean Sea), estimated to be $8 \mathrm{mmol} \mathrm{m}^{-2}$ $\mathrm{d}^{-1}$ as the mean value of an annual biometric survey (Canals \& Ballesteros 1997), and compares well with a net estimate over Palma Bay (Gazeau et al. 2005), largely dominated by Posidonia oceanica.

The results presented above, and their comparison with benthic and pelagic metabolic rates in the western Mediterranean Sea, provide new insights to the potential significance of rocky-shore shallow communities to the coastal $\mathrm{C}$ budget. 
Table 1. Range of metabolic data for macrophyte (mostly macroalgae)-dominated ecosystems. NWM: northwestern Mediterranean, GPP: gross primary production, $R$ : respiration, NCP: net community production, G: daily net calcification. Units - GPP, $R$ and ncp: $\mathrm{mmol} \mathrm{CO}_{2} \mathrm{~m}^{-2} \mathrm{~d}^{-1} ; G$ : $\mathrm{mmol} \mathrm{CaCO}_{3} \mathrm{~m}^{-2} \mathrm{~d}^{-1}$

\begin{tabular}{|c|c|c|c|c|c|}
\hline Type or location & GPP & $R$ & $\mathrm{NCP}$ & $G$ & Source \\
\hline Algal turf in coral reefs & $83-500$ & & & & Larkum (1983) \\
\hline Coral reef algal pavement zone & $167-583$ & $42-558$ & & $66-110$ & Kinsey (1985) \\
\hline Macroalgal-dominated coral reef community & 248 & 240 & & -0.8 & Gattuso et al. (1997) \\
\hline Macrophyte-dominated ecosystems (review) & $74-2762$ & $16-2493$ & -252 to 890 & & Gattuso et al. (1998) \\
\hline Temperate lagoon, seagrasses & $56-366$ & $103-381$ & & & Ziegler \& Benner (1998) \\
\hline Macroalgal-dominated coral community & $25-290$ & $32-272$ & -112 to 61 & & Falter et al. (2001) \\
\hline Macroalgal-dominated communities (review) & & $16-1271$ & & & Middelburg et al. (2005) \\
\hline Palma Bay, NWM & & & $10-20$ & 10 & Gazeau et al. (2005) \\
\hline Posidonia oceanica-vegetated sediments, NWM & $25-173$ & $18-142$ & -25 to 89 & 1.5 & Barrón et al. (2006) \\
\hline Calcareous-macrophyte-dominated, NWM & 519 & 500 & 19 & 8 & Present study \\
\hline
\end{tabular}

First, their primary production is 1 to 2 orders of magnitude larger than that of soft-bottom microphytobenthic (2.5 to $16 \mathrm{mmol} \mathrm{C} \mathrm{m} \mathrm{m}^{-2} \mathrm{~d}^{-1}$ ) or pelagic (20 mmol $\mathrm{C} \mathrm{m} \mathrm{m}^{-2} \mathrm{~d}^{-1}$ ) communities (Gazeau et al. 2004). As a result, their contribution to the $\mathrm{C}$ fluxes is comparatively larger in narrow continental shelf areas, which characterizes most of the Mediterranean Sea. Nonetheless, the balance between primary production and $R$ in macrophyte-dominated ecosystems (Gattuso et al. 1998, Gazeau et al. 2005, Barrón et al. 2006) results in NCP values that do not differ much from those of other systems. For example, NCP is $16 \mathrm{mmol} \mathrm{m}^{-2} \mathrm{~d}^{-1}$ for the Gulf of Lions (one of the so-called 'preferred LOICZ budget sites' in the Mediterranean Sea). On the other hand, benthic NCP over the 0 to $200 \mathrm{~m}$ depth range in the Mediterranean Sea was estimated to be -19.5 mmol C m ${ }^{-2} \mathrm{~d}^{-1}$ (Gazeau et al. 2004).

The shallow calcifying communities play a potentially significant role in the production of $\mathrm{CaCO}_{3}$ particles (Canals \& Ballesteros 1997). El Haïkali et al. (2004) have estimated that the calcification rate of Corallina elongata, the dominant species in the cove investigated in the present study, to be $140 \mathrm{mmol} \mathrm{CaCO}_{3} \mathrm{~m}^{-2}$ $\mathrm{d}^{-1}$. This value is much higher than the mean rate of $G$ estimated in the present study $\left(8 \mathrm{mmol} \mathrm{m}^{-2} \mathrm{~d}^{-1}\right)$. The discrepancy could be due to larger space integration, hence lower areal biomass and calcification rates and higher rates of calcification in seasons other than winter, but also reflects strong $\mathrm{CaCO}_{3}$ dissolution within the system. However, due to the ubiquitous presence of coralline algae in the Mediterranean Sea, calcification rates, even if modest compared to other systems, have the potential to significantly influence the regional carbon balance.

Acknowledgements. Thanks to J.-C. Romano for having initiated and followed this work, M. Lafont for invaluable technical assistance with the AMAM and B. El Haïkali for skillful assistance in the field and laboratory operations. N.B. acknowledges financial support of the Provence-Alpes-Côte d'Azur (PACA) Regional Council and the Nereides company.

\section{LITERATURE CITED}

Ballesteros E (1988) Composicion y estructura de la comunidad infralitoral de Corallina elongata Ellis \& Solander, 1786, de la Costa Brava (Mediterraneo occidental). Invest Pesq 52:135-151

Barnes DJ, Devereux MJ (1984) Productivity and calcification on a coral reef: a survey using $\mathrm{pH}$ and oxygen electrode techniques. J Exp Mar Biol Ecol 79:213-231

Barrón C, Duarte CM, Frankignoulle M, Borges AV (2006) Organic carbon metabolism and carbonate dynamics in a Mediterranean seagrass (Posidonia oceanica) meadow. Estuar Coast 29:417-426

Canals M, Ballesteros E (1997) Production of carbonate particles by phytobenthic communities on the MallorcaMenorca shelf, northwestern Mediterranean Sea. DeepSea Res II 44:611-629

Duarte CM, Middelburg JJ, Caraco N (2005) Major role of marine vegetation on the oceanic carbon cycle. Biogeosciences $2: 1-8$

El Haïkali B, Bensoussan N, Romano JC, Bousquet V (2004) Estimation of photosynthesis and calcification rates of Corallina elongata Ellis et Solander, 1786, by measurements of dissolved oxygen, $\mathrm{pH}$ and total alkalinity. Sci Mar 68:45-56

Falter JL, Atkinson MJ, Langdon C (2001) Productionrespiration relationships at different timescales within the Biosphere 2 coral reef biome. Limnol Oceanogr 46: $1653-1660$

Gattuso JP, Pichon M, Frankignoulle M (1995) Biological control of air-sea $\mathrm{CO}_{2}$ fluxes: effect of photosynthetic and calcifying marine organisms and ecosystems. Mar Ecol Prog Ser 129:307-312

Gattuso JP, Pichon M, Delesalle B, Canon C, Frankignoulle M (1996) Carbon fluxes in coral reefs. I. Lagrangian measurement of community metabolism and resulting air-sea $\mathrm{CO}_{2}$ disequilibrium. Mar Ecol Prog Ser 145:109-121

Gattuso JP, Payri CE, Pichon M, Delesalle B, Frankignoulle M (1997) Primary production, calcification and air-sea $\mathrm{CO}_{2}$ fluxes of a macroalgal-dominated coral reef community (Moorea, French Polynesia). J Phycol 33:729-738 
Gattuso JP, Frankignoulle M, Wollast R (1998) Carbon and carbonate metabolism in coastal aquatic ecosystems. Annu Rev Ecol Syst 29:405-434

Gattuso JP, Frankignoulle M, Smith SV (1999) Measurement of community metabolism and significance in the coral reef $\mathrm{CO}_{2}$ source-sink debate. Proc Natl Acad Sci USA 96: 13017-13022

Gattuso JP, Dawson NA, Duarte CM, Middelburg JJ (2005) Patterns of publication effort in coastal biogeochemistry: a bibliometric survey (1971 to 2003). Mar Ecol Prog Ser 294: $9-22$

Gazeau F, Smith SV, Gentili B, Frankignoulle M, Gattuso JP (2004) The European coastal zone: characterization and first assessment of ecosystem metabolism. Estuar Coast Shelf Sci 60:673-694

Gazeau F, Duarte CM, Gattuso JP, Barrón C and 7 others (2005) Whole system metabolism and $\mathrm{CO}_{2}$ fluxes in a Mediterranean Bay dominated by seagrass beds (Palma Bay, NW Mediterraean). Biogeosciences 2:43-60

Kinsey DW (1985) Metabolism, calcification and carbon production. I. System level studies. In: Proc 5th Int Coral Reef Congr, Vol 4. Antenne Museum-EPHE, Moorea, p 505-526

Langdon C (1993) Community respiration measurements using a pulsed $\mathrm{O}_{2}$ electrode. In: Kemp P, Sherr B, Sherr E (eds) Handbook of methods in aquatic microbial ecology. Lewis Publishers, Boca Raton, FL, p 447-453

Langdon C, Takahashi T, Marubini F, Atkinson M and 5 others (2000) Effect of calcium carbonate saturation state on the calcification rate of an experimental coral reef. Global Biogeochem Cycles 14:639-654

Langdon C, Broecke WS, Hammond DE, Glenn E and 5 others (2003) Effect of elevated $\mathrm{CO}_{2}$ on the community metabolism of an experimental coral reef. Global Biogeochem Cycles 17(1):11-1-11-14

Larkum AWD (1983) The primary productivity of plant communities on coral reefs. In: Barnes DJ (ed) Perspectives on coral reefs. Australian Institute of Marine Science, Townsville, p 221-230

Lefèvre $D$, Minas HJ, Minas $M$, Robinson $C$, Williams PJLB, Woodward MS (1997) Review of gross community production, primary production, net community produc-

Editorial responsibility: Otto Kinne (Editor-in-Chief), Oldendorf/Luhe, Germany tion and dark community respiration in the Gulf of Lions. Deep-Sea Res II 44:801-832

Lewis ER, Wallace DWR (1998) Program developed for $\mathrm{CO}_{2}$ calculations. ORNL/CDIAC-105, Carbon Dioxide Information Analysis Center, Oak Ridge National Laboratory, US Department of Energy, Oak Ridge

Littler MM (1980) Morphological form and photosynthesis performances of marine macroalgae: tests of a functional/ form hypothesis. Bot Mar 22:161-165

Mackenzie FT, Lerman A, Andersson AJ (2004) Past and present of sediment and carbon biogeochemical cycling models. Biogeosciences 1:11-32

Marsh JAJ, Smith SV (1978) Productivity measurements of coral reefs in flowing water. In: Stoddart DR, Joannes RE (eds) Coral reefs: research methods. Monographs on oceanographic methodology 5. UNESCO, Paris, p 361-377

Middelburg JJ, Duarte CM, Gattuso JP (2005) Respiration in coastal benthic communities. In: del Giorgio PA, Williams LBPJ (eds) Respiration in aquatic ecosystems. Oxford University Press, Oxford, p 206-224

Milliman JD (1993) Production and accumulation of calcium carbonate in the ocean: budget of a nonsteady state. Global Biogeochem Cycles 7:927-957

Morel A, Smith RC (1974) Relation between total quanta and total energy for aquatic photosynthesis. Limnol Oceanogr 19:591-600

Muller-Karger FE, Varela R, Thunell R, Luerssen R, Hu C, Walsh JJ (2005) The importance of continental margins in the global carbon cycle. Geophys Res Lett LO1602 32:1-4

Smith SV, Key GS (1975) Carbon dioxide and metabolism in marine environments. Limnol Oceanogr 20:493-495

Smith SV, Marsh JA (1973) Organic carbon production on the windward reef flat of Eniwetok atoll. Limnol Oceanogr 18: 953-961

Wollast R (1998) Evaluation and comparison of the global carbon cycle in the coastal zone and in the open ocean. In: Brink K, Robinson A (eds) The global coastal ocean: processes and methods. John Wiley \& Sons, New York, p 213-252

Ziegler S, Benner R (1998) Ecosystem metabolism in a subtropical, seagrass-dominated lagoon. Mar Ecol Prog Ser 173:1-12

Submitted: March 6, 2006; Accepted: August 21, 2006

Proofs received from author(s): March 6, 2007 